\title{
IAS/IFRS in Jordan: Adoption, Implementation and Determinants
}

\author{
Fawzi A. Al Sawalqa ${ }^{1, *}$, Atala Qtish ${ }^{2}$ \\ ${ }^{1}$ Accounting Department, Business Faculty, Tafila Technical University, Box 179, Tafila 66110, Jordan \\ ${ }^{2}$ Accounting Department, Economics \& Administrative Sciences Faculty, Al-Zaytoonah University, Amman, Jordan
}

Received February 18, 2021; Revised March 24, 2021; Accepted April 22, 2021

\section{Cite This Paper in the following Citation Styles}

(a): [1] Fawzi A. Al Sawalqa, Atala Qtish, "IAS/IFRS in Jordan: Adoption, Implementation and Determinants," Universal Journal of Accounting and Finance, Vol. 9, No. 2, pp. 232 - 244, 2021. DOI: 10.13189/ujaf.2021.090213.

(b): Fawzi A. Al Sawalqa, Atala Qtish (2021). IAS/IFRS in Jordan: Adoption, Implementation and Determinants. Universal Journal of Accounting and Finance, 9(2), 232 - 244. DOI: 10.13189/ujaf.2021.090213.

Copyright $\bigcirc 2021$ by authors, all rights reserved. Authors agree that this article remains permanently open access under the terms of the Creative Commons Attribution License 4.0 International License

\begin{abstract}
This study examines the current status of accounting standards among Jordanian firms. In particular, it examines the adoption level of IAS/IFRS. In addition, it examines the implementation process in terms of difficulties and challenges. Further, the study tests empirically the effect of international institutional pressures, local legal enforcement bodies and accounting education level on accounting standards adoption level. The results of the study are based on the descriptive and multiple regression analysis technique. Based on 62 usable responses, the study reveals that the adoption level of IAS/IFRS among Jordanian firms is moderate. For example, IFRS 7 (Financial Instruments: Disclosure) is the most adopted standard. This is followed by IAS 32 (Financial Instruments: Presentation) and IFRS 15 (Revenue from Contracts with Customers) respectively, while IFRS 2 (Share-based Payment) is the least adopted standard. In general, the study reveals that the implementation process of some standards is easy such as IFRS 7 (Financial Instruments: Disclosure), while others such as IAS 36 (Impairment of Assets) and IFRS 13 (Fair Value Measurement) need additional efforts to properly implement. In addition, several challenges were detected, which could prevent the proper implementation of some accounting standards such as the shortage in the governmental and IT supports. Further, the study shows that international institutional pressure and local legal enforcement bodies have a positive and significant relationship with the adoption level of accounting standards, while the effect of accounting education level is insignificant. JACPA should coordinate and collaborate
\end{abstract}

with IASB and the government to offer all the necessary financial, technical and legal support for Jordanian firms to fully adopt and apply accounting standards. Several recommendations were offered for future research to enrich this vital topic in Jordan and other developing countries.

Keywords IFRS Adoption, IFRS Implementation, International Institutional Pressure, Local Legal Enforcement, JACPA

\section{Introduction}

It can be argued that International Accounting Standards are the engine of accounting profession, especially in those markets where much weight has been given to the precise application for different accounting practices. This, however, is mainly true in developed markets and this is also valid in some specific sectors in developing markets that have solid legal power to impose firms to comply with the different aspects of accounting standards. The motivation of the current study is based on two main reasons: first, the complicated nature of some standards, which creates some doubt on the adoption level of them; second, the ambiguity that is surrounded the relationship of some factors with the adoption level of accounting standards.

Nevertheless, more emphasis has been given to some issues in current accounting standards studies, such as 
convergence and harmonization, even in developing countries [e.g. 1]. Accounting standards come to enhance and support the transparency of accounting information and to prevent some unacceptable practices like financial statements smoothing [2]. In developed markets, firms can efficiently apply any accounting technique, while in case of less developed markets additional challenges are in place. Thus, the actual implementation of accounting standards is not an easy task in Jordan and other emerging markets [3, 4]. For example, it has been argued that some standards are difficult to understand and apply, even in some developed countries [5, 6]. Most of the prior studies focused on examining the adoption consequences of accounting standards [e.g. 7-11] and ignored the level and determinants of such adoption. Accordingly, it is rational to argue that there is some doubt in the adoption level of such standards among Jordanian companies. Therefore, the current study comes firstly to investigate the adoption level of international accounting standards in Jordan. In addition, the extent of appropriateness of such standards to Jordanas a developing country- is ambiguous. Therefore, many challenges and difficulties should be identified in the implementation stage of such standards in Jordan. In this context, Jermakowicz and Gornik-Tomaszewski [6] call for additional studies to explain the difficulties of IFRS application.

However, Samaha and Khlif [12] found that only few studies have focused on the effect of regulations and institutional pressure on the IFRS adoption in developing countries [e.g. 13]. Thus, current study also focuses on the determinants of adoption level of accounting standards. However, the problem in case of Jordan is in the adoption level and the implementation process of IFRS. Therefore, the current study does not focus on the harmonization or the adoption decision of IFRS in Jordan. ${ }^{1}$ Instead, this study focuses on standardization [15].

Based on the above discussion, the current study comes to bridge the gap in the previous studies that centered mainly on developed countries and to investigate the different issues of concern to preparers, managers, auditors, academics and users in Jordanian business market through achieving the following objectives:

1. To identify the adoption level of IAS/IFRS among Jordanian firms.

2. To identify the difficulty level and challenges of IAS/IFRS implementation among Jordanian firms.

3. To identify the main factors that may associate with the adoption level of IAS/IFRS in Jordan.

However, the next two sub-sections focus on the theoretical framework of the study and the Jordanian accounting standards environment. Section two reviews the prior studies in the field and presents the hypotheses.

1 According to Flynn (14, p.5) harmonization means, "the reduction of difference in accounting differences among countries".
Section three presents the study methods. Section four discusses the study results and finally section five concludes the study.

\subsection{Theoretical Framework}

Those standards issued from 2002 are called International Financial Reporting Standards (IFRS) [e.g. 16] and are developed to replace some old International Accounting Standards (IAS) or to cover matters that are not covered previously in IAS [e.g. 17]. As shown in Table 1, IASB is the professional body responsible for issuing, and harmonizing IFRS in all over the world [e.g. 18,14,19], and the International Financial Reporting Interpretations Committee (IFRIC) is the explanatory group of IASB and is responsible for issuing the interpretations of IFRS [e.g. 20,16]. ${ }^{2}$ Notably, before emersion of IASB, the International Accounting Standard Committee (IASC) issued 41 IAS and the Standing Interpretations Committee (SIC) -interpretive body of IASC- issued 33 interpretations for IAS [e.g. 20]. ${ }^{3}$

Table 1. Professional and interpretive body of accounting standards

\begin{tabular}{|c|c|c|}
\hline Period & Professional body & Interpretive body \\
\hline Before 2002 & IASC & SIC \\
\hline $\begin{array}{c}\text { Since 2002- Till } \\
\text { now }\end{array}$ & IASB & IFRIC \\
\hline
\end{tabular}

Source: Based on the graph No. 1 of Erzsébet and Suhányi [16, p. 269].

Several definitions of IFRS were suggested in prior studies [e.g. 2, 20]. IASB seeks to enrich the value of accounting information $[23,21]$ by promoting IFRS among countries [e.g. 2, 14], and to deepen the transparency and comparability of financial statements [24]. IASB also established the Accounting Standards Advisory Forum (ASAF) in 2012 to enhance the promotion process of IFRS among countries [e.g. 22]. Notably, IASB has not the necessary legal power on companies or countries to adopt IFRS [e.g. 2]. Instead, the enforcement power comes from the legal bodies of each country [25] such as Securities Law in case of Jordan.

As shown in section 2.2 below, three explanatory variables have been selected to test empirically their effect on the adoption level of IAS/IFRS. The explanatory variables include international institutional pressure, local legal enforcement bodies and accounting education level.

\subsection{Accounting Standards in Jordan}

Since Jordan has not its own accounting standards, Jordanian Association of Certified Public Accountants

2 IASB was founded in 1973 with a name of International Accounting Standards Committee (IASC) until 2001 when it was renamed to International Accounting Standards Board [21, 20]; for more details, see, for example, Deloitte and Touche [22].

3 Both IASC and SIC were replaced by IASB and IFRIC respectively [e.g. $20,16]$. 
(JACPA) along with 1997 Companies Law and the 2002 Securities Law have stressed the adoption of IAS/IFRS [e.g. $26,27]$. Thus, it is compulsory to adopt the international accounting standards by Jordanian companies since 1990 according to both Securities Law and Companies Law [e.g. 27].

Jordan is a member in IASB through JACPA, and firms are controlled by several local professional and governmental institutions such as Jordan Securities Commission (JSC) through Securities Law, JACPA through Accountancy Profession Law, Central Bank through Banking Law, Companies Control Department (CCD) through companies' law [e.g. 26]. Therefore, one of the current study objectives is to show the effect of such local enforcement bodies on the adoption of accounting standards in Jordan.

\section{Literature Reviews and Hypotheses}

Most of the previous research in the field focused on the effect of using international standards (i.e. IFRS/IAS) instead of local standards on the quality of accounting information and any other potential benefits for such adoption. These include, for example, Callao, Jarne and Laínez [28] in Spain; Liu et al. [29] in China; Terzi, Oktem and Sen [30] and Aksu and Espahbodi [31] in Turkey; Săcărin, Bunea and Gîrbină [32] in Romania; Grabinski, Kedzior and Krasodomska [33] in Poland; Khan et al. [34] and DiPonio [35] in Canada. The current study focuses on two main issues including firstly, the adoption level and implementation of the accounting standards in terms of difficulties and challenges and secondly, the main determinants of adoption level. Thus, the next sub-sections focus on the prior studies on these topics.

\subsection{Adoption of Accounting Standards}

Most of the countries have started to converge their local accounting standards with international standards early [36]. ${ }^{4}$ For example, on November 2007 the Securities Exchange Commission (SEC) required foreign firms to use only IFRS in preparing their statements [22, 37]. This change has taken place due to the joint efforts between IASB and U.S Financial Accounting Standard Board (FASB) to promote accounting standards universally [14, 38]. ${ }^{5}$ In this context, Eng, Sun and Vichitsarawong [37] found that accounting figures that were reported using U.S. GAAP before 2007 were equivalent to those reported under IFRS after 2007. This modification has also taken place in European Union (EU) countries where the European

4 Convergence is "the process of narrowing differences between IFRS and the accounting standards of countries that retain their own standards" [2, p.9].

5 IASB and FASB have signed the Norwalk Agreement in 2002, which represents "a roadmap" to converge accounting standards [14, p.4].
Commission (EC) asked all public firms to prepare their consolidated statements under IFRS as of January 1, 2005 [e.g.39, 36,40,2, 41, 42, 19]. Notably, some countries such as South Africa are early switched to IFRS [43]. Similarly, some other developing countries in Middle East such as Jordan and some Gulf Cooperation Council (GCC) countries have early adopted the international accounting standards $[44,45]$.

Despite a broad set of benefits that IAS/IFRS can offer to accounting reporting process and business markets, still there are many challenges that limit the effective implementation of such standards. In this context, it has been argued that IFRS implementation is not an easy task, as some standards are unclear and complex for users and even for auditors and preparers to deal with effectively [e.g. $40,5,46,4,47,48]$. For example, the study conducted by Jermakowicz and Gornik-Tomaszewski [6] reported many challenges in respect to the implementation of IFRS in EU countries, including, for example, the difficulty of applying some standards like IAS 12, IAS 19, IAS 32, IAS 36, IAS 38, IAS 39, IFRS 2 and IFRS 3, and the lack of implementation directions, IT systems and knowledge [see also $40,5,49]$.

Hail et al. [50] argued that a shift from GAAP to IFRS in USA is not an easy mission due to many political challenges and additional costs of such switching [see also, 33]. In India, Srivastava and Bhutani [3] performed a study to assess the respondents' perceptions toward the adoption of IFRS in India and found that users have very little knowledge about the contents and implementation process of IFRS [see also, 51]. The study conducted by Săcărin, Bunea and Gîrbină [32] indicated that the main challenges in application IFRS in Romania are IT applications, trainings and other associated costs. Similarly, Kılıç, Uyar and Ataman [52] found that the associated costs of standard implementation may affect the potential benefits in Turkey [see also, 47].

As indicated above, most of the implementation challenges are centered on the difficulty of IFRS contents, knowledge and other associated costs. That is, the theoretical framework of some standards is not clear enough to understand. In addition, the lack of knowledge among different users is another important challenge that may affect the effective implementation of accounting standards.

\subsection{Determinants of IFRS Adoption Level}

It has been argued and found that the adoption of IAS/IFRS is related to several factors [e.g.53, 2, 50]. These include, for example, the nature of financial markets [21], the nature of applicable laws (e.g. Anglo-Saxon law) [54], legal power [55] institutional pressure [56, 57]. In this context, it has been argued that several economic and legal elements may affect the adoption level of accounting standards among countries [e.g. 44, 50, 57, 58, 59, 4]. For 
example, Barlev and Haddad [21] argued that accounting and governmental organizations along with international business relations are key players in promoting the accounting standards among countries. In addition, Hail et al. [50] argued that adoption of IFRS in USA is not an easy decision; instead, many economic and political factors need to be considered.

Others such as Lasmin [57] stressed the critical role of corporate characteristics in supporting the usage and adoption of accounting standards. In addition, El-Helaly, Ntim and Al-Gazzar [13] found that corruption is an important determinant for IFRS adoption. The audit quality is also an important factor for firms to adopt accounting standards [60].

Based on the above discussion, it can be argued that the institutional pressure of international organizations, mainly those offer aids to Jordan, have contributed in some way to the adoption of IAS/IFRS in Jordan. In addition, the institutional pressures from some national organizations and legal bodies have also affected such adoption. Another important issue is the accounting knowledge. These three factors are the material of the next three sub-sections of this paper.

\subsection{International Institutional Pressure}

It has been argued that adoption of accounting standards in some emerging markets is inspired by the international institutional pressure [e.g. 57]. In this context, Mir and Rahaman [56] performed a study to investigate the factors that may control the decision of Bangladesh Government in adoption IAS. As indicated from the study, the business environment in Bangladesh -as a developing country- is almost similar to that of Jordan in that it subjects to the institutional pressure from several international organizations such as World Bank and International Monetary Fund. Similar result was found by Lasmin [57]. Alia and Joel [61] also stressed the important role of international audit firms and other international firms in adopting IFRS by Jordanian firms. Mande [62] also found that the need for external investments forced some African countries to adopt international standards [see also, 21]. In the same context, Damak -Ayadi, Sassi and Bahri [63] found that foreign aid has a major impact on IFRS adoption. Similarly, Sharairi [64] found that international institutional pressure is also an important and critical factor in adoption IFRS. Based on the above discussion, it can be hypothesized that:

H1. There is a positive and significant relationship between the international institutional pressure and the adoption level of accounting standards in Jordan.

\subsection{Local Legal Enforcement Body}

According to Brown, Preiato and Tarca [65, p. 2] enforcement bodies have the necessary power to force firms to apply accounting standards. Thus, for the purpose of this sub-section, the enforcement bodies include the legal bodies in terms of laws and institutions that govern and control the adoption of accounting standards.

It has been argued that regulations of any country should be formulated to adopt accounting standards [61], due to their critical role in fixing the usage of different accounting practices [47]. In this context, the main challenges that the adoption of international accounting standards may face is the lack of national legislative systems necessary to manage the adoption of such standards in some countries [e.g. 66, 40]. Thus, regulations should facilitate the use of accounting standards by accomplishing the necessary amendments to them. In addition, related regulations should determine obviously a beginning date for companies to adopt standards [61]. For example, JACPA determined January 1990 as the effective date for adopting IFRS in Jordan [e.g. 26, 61].

Empirically, several prior studies [e.g.55, 18, 12] found that strong legal enforcement body has significantly promoted the adopting of IFRS. In the same context, findings by some prior studies [e.g. 54, 67] indicated that adoption of IFRS spread over countries that have a solid legal enforcement system. One obvious example is the adoption of IFRS by Romania due to the enforcement power of European Union regulations [68]. Similarly, the local organizations have also the enforcement power to supervise and control the adoption of accounting standards. For example, Pekdemir and Türel [69] found that ineffective control has affected the implementation of IAS/IFRS negatively in Turkey. Burnett et al. [70] found that larger Canadian firms with legal enforcement power have been interested in applying IFRS. Sharairi [64] found that local institutions have significantly contributed to the adopting of IFRS by Islamic banks. Damak-Ayadi, Sassi and Bahri [63] also found that legal enforcement power has positively and significantly impacted the accounting standards adoption. Accordingly, it can be hypothesized:

H2. There is a positive and significant relationship between the local legal enforcement bodies and the adoption level of accounting standards in Jordan.

\subsection{Accounting Education Level}

It has been noted that the adoption of IFRS needs a well education, especially in terms of accounting and its related issues. The problem is small for those who have certificates in accounting or other related field, but this is not the case for several types of users. Therefore, it is the duty of accounting professional bodies to offer the necessary programs, seminars, and training courses to the preparers to effectively implement accounting standards. In addition, such professional bodies are required to give the essential amendments to the accounting curricula in universities. In this context, Gornik-Tomaszewski and Showerman [20] stressed the coordination between universities and the 
different accounting professional bodies to accomplish the required amendments to accounting curricula to be in line with IAS/IFRS [see also, 71]. Similar argument is offered by Akgün [72] in respect to accountant in that they should have all the necessary knowledge to deal with accounting standards.

Empirically, several results [e.g. 73, 57, 54] stressed the importance of accounting education for accounting standards adoption. Similarly, Alsaqqa and Sawan [18] findings indicated that education level and unavailability of qualified accountants are the main challenges that are associated with IFRS adoption in UAE. Thus, it can be hypothesized that:

H3. There is a positive and significant relationship between the accounting education level and the adoption level of accounting standards in Jordan.

\section{Methods}

\subsection{Sample and Data}

The current study seeks to collect a specific type of data about an important topic. Therefore, the decision has been taken to select the quantitative approach over other approaches to collect the data. Thus, the questionnaire is the main instrument for collecting the study data. The potential respondents should have the necessary experience in their companies and are in touch with the accounting standards implementation. The appropriate potential respondents include, for example, financial managers, financial manager assistant, heads of accounting departments, internal auditors and accountants.

The questionnaire includes seven sections. Section one includes the demographic information of respondents. Section two has 15 accounting standards and asks the respondents to rank the adoption level of them. The 15 standards were selected due to their frequent usage among the different types of firms. In addition, 6 standards were selected from these standards to identify their implementation difficulty level. Thus, section three has 6 accounting standards and asks respondents to rate them according to the implementation difficulty level. Section four includes 11 questions summarize the challenges that may face Jordanian companies in implementation the accounting standards. These challenges were adapted from prior studies in the field [e.g. 74, 40, 5, 6, 75, 4]. Other sections (i.e. five, six and seven) focuses on the determinants of accounting standards adoption level. Three factors were selected to identify their effect on the adoption of accounting standards by Jordanian companies. These include international institutional pressure, legal enforcement bodies and accounting educational level. The international institutional pressure includes 10 international organizations such as World Bank [e.g. 56, 26, 12]. The local enforcement bodies include five local institutions and laws [e.g. 26, 61, 65]. Finally, accounting education level includes three questions [e.g. 73, 18, 54].

However, 80 questionnaires were distributed randomly on the Jordanian listed companies. The study population includes 180 listed and traded firms. Due to the restrictions and potential risks of the COVID Pandemic, only 80 questionnaires were handed to 80 firms distributed over four sectors including banking, insurance, industrial and services sector. The continuous follow-up with the firms resulted in collecting 73 questionnaires. 11 unusable questionnaires were excluded. This gives 62 usable questionnaires $(77.5 \%)$. Table 2 shows that most of the respondents $(95.2 \%)$ are males. The respondents' ages range between 30 and 50 years. $67.7 \%$ of the respondents have bachelor degrees and $27.4 \%$ have master degrees. $61.3 \%$ of the respondents are specialized in accounting. About $71 \%$ of the respondents have experience in their firms of 5 years or above. $58.1 \%$ of the respondents are accountants and about $19.4 \%$ are heads of accounting departments. Finally, the study sample is distributed over four sectors including baking, insurance, industrial and services. 
Table 2. Demographic characteristics of respondents

\begin{tabular}{|c|c|c|c|c|c|}
\hline & Frequency & $\%$ & & Frequency & $\%$ \\
\hline Gender & & & Experience & & \\
\hline Male & 59 & 95.2 & Less than 5 years & 18 & 29.0 \\
\hline Female & 3 & 4.8 & 5- less than 10 & 33 & 53.2 \\
\hline Total & 62 & 100.0 & 10- less than 15 & 7 & 11.3 \\
\hline Age & & & 15- less than 20 & 4 & 6.5 \\
\hline Less than 30 & 9 & 14.5 & Total & 62 & 100.0 \\
\hline 30- less than 40 & 27 & 43.5 & Position & & \\
\hline 40- less than 50 & 17 & 27.4 & Financial manager & 4 & 6.5 \\
\hline 50 or above & 9 & 14.5 & Financial manager assistant & 6 & 9.7 \\
\hline Total & 62 & 100.0 & Head of accounting Dep. & 12 & 19.4 \\
\hline Qualification & & & Internal auditor & 3 & 4.8 \\
\hline $\mathrm{PhD}$ degree & 1 & 1.6 & Accountant & 36 & 58.1 \\
\hline Master degree & 17 & 27.4 & Others & 1 & 1.6 \\
\hline Bachelor degree & 42 & 67.7 & Total & 62 & 100.0 \\
\hline Diploma & 2 & 3.2 & Sector & & \\
\hline Total & 62 & 100.0 & Banking & 11 & 17.7 \\
\hline Specialization & & & Insurance & 12 & 19.4 \\
\hline Accounting & 38 & 61.3 & Industrial & 17 & 27.4 \\
\hline Business administration & 13 & 21.0 & Services & 22 & 35.5 \\
\hline Economy & 8 & 12.9 & Total & 62 & 100.0 \\
\hline Finance & 3 & 4.8 & & & \\
\hline Total & 62 & 100.0 & & & \\
\hline
\end{tabular}

\section{Results and Discussion}

\subsection{Descriptive Analysis Results}

This sub-section presents the descriptive results of study that related to the objective one and objective two.

\subsubsection{Level of Adoption}

The first objective strives to identify the adoption level of IAS/IFRS among Jordanian listed companies. 15 standards were selected due to their common usage among different companies and sectors. Table 3 shows the level of adoption of IAS/ IFRS among Jordanian companies using a five-point Likert scale ( $1=$ not adopted at all; $5=$ adopted to a very great extent). IFRS 7 ranked first with a mean value of 4.0484. This is due to the emphasis of different
Jordanian legislative bodies on the disclosure issues. IAS 32 ranked second with a mean value of 3.9677. This is followed by IFRS 15 with a mean of 3.9516. IFRS 16 ranked fourth (3.9032). IFRS 8 ranked fifth with a mean value of 3.8548. IFRS 12 ranked sixth with a mean value of 3.8387. IFRS 13 ranked seventh and IAS 10 ranked eighth. This is followed by both IAS 36 and IAS 16 which ranked ninth with mean values of 3.7097 for both of them. However, the results show that IFRS 2 ranked last with a mean value of 2.9032 .

In general, it looks that the level of adoption of IAS/IFRS among Jordanian companies is moderate as the overall mean value is 3.6667 . Accordingly, the study in the next two sub-sections discusses the difficulties and challenges that may affect the level of adoption. 
Table 3. Level of IAS/ IFRS adoption

\begin{tabular}{|c|c|c|c|}
\hline IAS/IFRS & Rank & Mean & S.D. \\
\hline IFRS7: Financial instruments: disclosure & 1 & 4.0484 & .73390 \\
\hline IAS 32: Financial Instruments: Presentation & 2 & 3.9677 & 1.02378 \\
\hline IFRS 15: Revenue from Contracts with Customers & 3 & 3.9516 & .87642 \\
\hline IFRS 16: Leases & 4 & 3.9032 & .97021 \\
\hline IFRS 8: Operating segments & 5 & 3.8548 & .93820 \\
\hline IFRS 12: Disclosure of interests in other entities & 6 & 3.8387 & 1.01131 \\
\hline IFRS 13: Fair Value Measurement & 7 & 3.8226 & 1.03265 \\
\hline IAS 10: Events After the Reporting Period & 8 & 3.7903 & 1.01039 \\
\hline IAS 36: Impairment of Assets & 9 & 3.7097 & .94760 \\
\hline IAS 16: Property, Plant and Equipment & 9 & 3.7097 & 1.01444 \\
\hline IAS 19: Employee Benefits & 11 & 3.5323 & 1.21085 \\
\hline IFRS1: First-time Adoption of IFRSs & 12 & 3.4194 & 1.26165 \\
\hline IAS 26: Accounting and Reporting by Retirement Benefit Plans & 13 & 3.3871 & 1.15026 \\
\hline IFRS 5: Non-current assets held for sale and discontinued operations & 14 & 3.1613 & 1.04322 \\
\hline IFRS 2: Share-based payment & 15 & 2.9032 & 1.18335 \\
\hline Total & 3.6667 & \\
\hline
\end{tabular}

One Way ANOVA test has been used to test if there is a difference in the adoption level of IAS/IFRS among different sectors. As shown in Table 4, the result is insignificant $(\mathrm{F}=0.748 ; \mathrm{p}=0.528)$. Therefore, it can be concluded that the level of IAS/IFRS adoption among Jordanian firms is not different due to sector type according to the respondents.

Table 4. One Way ANOVA test

\begin{tabular}{|c|c|c|c|c|c|c|}
\hline Factor & & $\begin{array}{c}\text { Sum of } \\
\text { Squares }\end{array}$ & $\mathrm{df}$ & $\begin{array}{c}\text { Mean } \\
\text { Square }\end{array}$ & $\mathrm{F}$ & Sig. \\
\hline \multirow{5}{*}{ Sector } & $\begin{array}{c}\text { Between } \\
\text { Groups }\end{array}$ & .599 & 3 & .200 & .748 & .528 \\
\cline { 2 - 7 } & $\begin{array}{c}\text { Within } \\
\text { Groups }\end{array}$ & 15.473 & 58 & .267 & & \\
\cline { 2 - 8 } & Total & 16.071 & 61 & & & \\
\hline
\end{tabular}

\subsubsection{Difficulty Level of Accounting Standards}

To identify the difficulty level of some accounting standards, respondents were asked to rank 6 standards according to their difficulty on a five-point-likert scale ( $1=$ very difficult; $5=$ very easy). The 6 standards were selected from the 15 standards that are used to identify the adoption level as shown in Table 3 above. As shown in Table 5, it looks that IAS 36 is the most difficult standard. This result is consistent with that of Larson and Street [40]; Hoogendoorn [5] and Jermakowicz and Gornik-Tomaszewski [6]. This is followed by IFRS 13: "Fair value measurement". The justification for these two results is the unavailability of the necessary tools to deal with these two standards such as the absence of active market in Jordan to determine the fair value effectively. In this context, Jermakowicz and Gornik-Tomaszewski [6] argued that using fair value as a measurement tool has affected the adoption of IFRS negatively. IFRS 15 ranked third with a mean value of 4.2097 and followed by IAS 16 . IAS 19 ranked fifth with a mean value of 4.2581 . IFRS 7 is the least difficult standard with a mean value of 4.3226 . However, it looks that IAS/IFRS are, in general, easy as the overall mean value (4.1935) closer to "easy".

Table 5. Difficulty level of IAS/IFRS implementation

\begin{tabular}{|c|c|c|c|}
\hline IAS/IFRS & Rank & Mean & S.D. \\
\hline IAS 36: Impairment of Assets & 1 & 4.0323 & .97456 \\
\hline $\begin{array}{c}\text { IFRS 13: Fair Value } \\
\text { Measurement }\end{array}$ & 2 & 4.1129 & .92515 \\
\hline $\begin{array}{c}\text { IFRS 15: Revenue from } \\
\text { Contracts with Customers }\end{array}$ & 3 & 4.2097 & .65630 \\
\hline $\begin{array}{c}\text { IAS 16: Property, Plant and } \\
\text { Equipment }\end{array}$ & 4 & 4.2258 & .68758 \\
\hline IAS 19: Employee Benefits & 5 & 4.2581 & .69978 \\
\hline $\begin{array}{c}\text { IFRS 7: Financial instruments: } \\
\text { disclosure }\end{array}$ & 6 & 4.3226 & .95427 \\
\hline Total & & 4.1935 & \\
\hline
\end{tabular}

\subsubsection{Accounting Standards Implementation Challenges}

To determine the challenges that may confront Jordanian companies in implementing accounting standards, respondents were also asked on a five-point Likert-scale to rank 11 potential challenges for IAS/IFRS implementation, where, $1=$ strongly disagree and $5=$ strongly agree. As shown in Table 6 , the lack of government support to apply the accounting standards ranked first with a mean value of 3.5806. This is followed by a technical challenge that related to the lack of necessary IT systems to implement standards. This result is consistent with the findings of Jermakowicz and Gornik-Tomaszewski [6] and Săcărin, 
Bunea and Gîrbină [32]. The deficiency in the accounting legislations necessary to implement standards is ranked third with a mean value of 3.3871 . This is also one of the main challenges of accounting standards implementations as outlined by Jermakowicz and Gornik-Tomaszewski [6]. The highly costs are ranked fourth (3.3065). In this context, Hail et al. [50] argued that adoption of IFRS is costly. In addition, this result is consistent with that of Jermakowicz [74] and Kilıç, Uyar and Ataman [52]. Lack of holding seminars and training courses to implement standards by JICPA is ranked fifth (3.2258). This result is in line with the findings of Săcărin, Bunea and Gîrbină [32] and affects the necessary knowledge to apply standards negatively [e.g. 3, 47]. Difficulty of implementing some standards in practice is ranked sixth with a mean value of 3.2097. In the same context, difficulty of understanding the theoretical framework of some standards ranked also sixth. These two results are due to the complexity of some standards $[6,46]$. Lack of IASB experts in Jordan ranked eighth with a mean of 3.1452. In this context, findings from Dayyala, Zaidi and Bagchi [76] revealed that collaboration among countries and IASB is one of the main factors that help in adopting and applying IFRS. Lack of active market in Jordan ranked ninth with a mean of 3.0968. The last two challenges are lack of Arabic language version of standards and the small number of professional accountants and auditors in Jordan.

\subsection{Hypotheses Testing}

To determine the main factors that are associated with IAS/IFRS adoption, this section presents the empirical results of the study. The initial results of Cronbach Alpha reveal that ACCEDU has low reliability (0.459) with its original 3 items. Due to the importance of ACCEDU to the study model, the test of reliability is repeated with "scale if item deleted" on SPSS program. The result reveals that when deleting the third item, the reliability will be enhanced (0.562). Therefore, ACCEDU is included in the regression model with two items. Table 7 shows the descriptive statistics for the study variables. All the Cronbach's alpha values are more than 0.50 [77]. Equation 1 shows the study model and variables.

$$
\begin{gathered}
\mathrm{ADLEVL}=\beta_{0}+\beta_{1} \mathrm{ININPR}+\square_{2} \mathrm{LOLEBO}++\square_{3} \\
\text { ACCEDU }+\mathrm{e}
\end{gathered}
$$

Where:

$A D L E V L=$ adoption level of IAS/IFRS; ININPR = international institutional pressure; $L O L E B O=$ local legal enforcement bodies; $A C C E D U=$ accounting education level; and e= error term.

\begin{tabular}{|c|c|c|c|c|}
\hline No. & Challenge & Rank & Mean & S.D. \\
\hline 7 & lack of government support to apply the standards effectively & 1 & 3.5806 & 1.09467 \\
\hline 11 & lack the necessary IT systems to implement standards & 2 & 3.5161 & 1.26416 \\
\hline 8 & Deficiency in the accounting legislations necessary to apply standards & 3 & 3.3871 & 1.06131 \\
\hline 10 & Highly costs of implementation & 4 & 3.3065 & 1.19547 \\
\hline 6 & Lack of holding seminars and training courses to implement standards by JICPA & 5 & 3.2258 & 1.23367 \\
\hline 3 & Difficulty of implementing some standards in practice. & 6 & 3.2097 & 1.29485 \\
\hline 2 & The difficulty of understanding the theoretical framework of some standards & 6 & 3.2097 & 1.35667 \\
\hline 5 & lack of IASB experts in Jordan & 8 & 3.1452 & 1.22604 \\
\hline 1 & Lack of active capital market & 9 & 3.0968 & 1.60644 \\
\hline 4 & lack of Arabic language version of standards & 10 & 2.6452 & 1.44967 \\
\hline \multirow[t]{2}{*}{9} & The small number of professional accountants and auditors in Jordan & 11 & 2.4194 & 1.26165 \\
\hline & Total & & 3.1584 & \\
\hline
\end{tabular}

Table 6. Challenges of accounting standards implementation

Table 7. Descriptive statistics for study variables

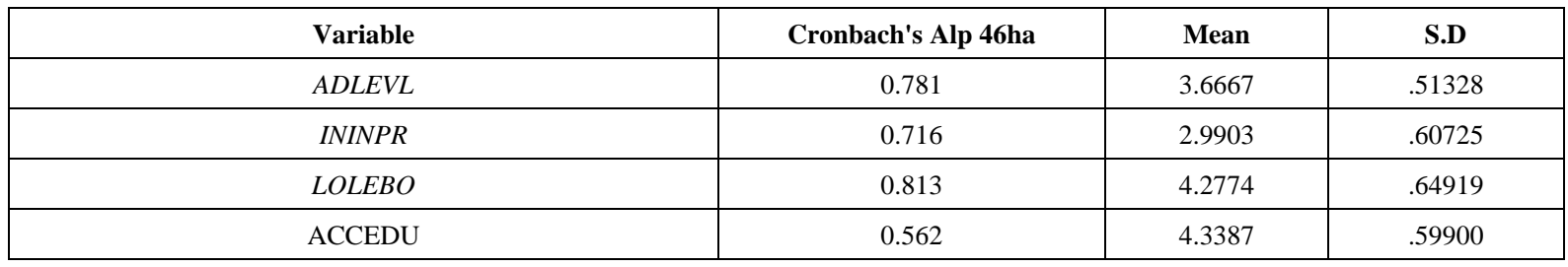


Table 8 shows the correlation matrix. The correlations between explanatory variables indicate nonexistence of Multicollinearity. The Matrix also shows a significant association between ININPR, LOLEBO and the dependent variable, while the association between ACCEDU and the dependent variable is insignificant.

Table 8. Correlation Matrix

\begin{tabular}{|c|c|c|c|c|}
\hline Variable & ADLEVL & ININPR & LOLEBO & ACCEDU \\
\hline ADLEVL & 1 & & & \\
\hline ININPR & $0.277^{*}$ & 1 & & \\
\hline LOLEBO & $0.360^{* *}$ & 0.140 & 1 & \\
\hline ACCEDU & 0.222 & -0.049 & $0.277^{*}$ & 1 \\
\hline
\end{tabular}

** Correlation is significant at the 0.01 level. * Correlation is significant at the 0.05 level.

Table 9 shows the hypotheses testing results. The study model is appropriate $(\mathrm{F}=4.970 ; \mathrm{p}=0.004)$. The results show that the relationship between ININPR and ADLEVL is positive and significant at the 0.05 level $(\mathrm{t}=2.067$; $\mathrm{p}=0.043$ ). Thus, $\mathrm{H} 1$ is accepted. Therefore, it can be concluded that there is a positive and significant relationship between the international institutional pressure and the adoption level of accounting standards in Jordan. This result is in line with the argument of Ionaşcu et al. [68] and the findings of several prior studies [e.g. 56, 57, 61, 62, $78,64,63]$.

Table 9. Multiple regressions analysis results

\begin{tabular}{|c|c|c|c|c|c|}
\hline $\begin{array}{c}\text { Independent } \\
\text { variables }\end{array}$ & & t-value & Sig. & Tol. & VIF \\
\hline CONSTANT & & 2.549 & 0.013 & & \\
\hline ININPR & & 2.067 & 0.043 & .972 & 1.029 \\
\hline LOLEBO & & 2.288 & 0.026 & .900 & 1.112 \\
\hline ACCEDU & & 1.274 & 0.208 & .915 & 1.093 \\
\hline $\mathrm{R}$ & 0.452 & & & & \\
\hline $\mathrm{R}^{2}$ & 0.204 & & & & \\
\hline Adjusted R ${ }^{2}$ & 0.163 & & & & \\
\hline $\mathrm{F}$ & 4.970 & & & & \\
\hline Sig. & 0.004 & & & & \\
\hline Cook's Distance & 0.025 & & & & \\
\hline $\begin{array}{c}\text { Centered } \\
\text { Leverage Value }\end{array}$ & 0.048 & & & & \\
\hline Durbin-Watson & 1.689 & & & & \\
\hline
\end{tabular}

Similarly, the results also show a positive and significant $(\mathrm{t}=2.288, \mathrm{p}=0.026)$ relationship between LOLEBO and ADLEVL. Therefore, $\mathrm{H} 2$ is also accepted. Thus, it can be concluded that there is a positive and significant relationship between the local legal enforcement bodies and the adoption level of accounting standards in Jordan. Notably, the effect of LOLEBO on ADLEVL is stronger than that of ININPR. However, this significant relationship is also consistent with several prior findings [e.g. 55, 18, 68, $70,12,64,63]$.
Finally, results show insignificant $(\mathrm{t}=1.274, \mathrm{p}=0.208)$ relationship between ACCEDU and ADLEVL. Therefore, $\mathrm{H} 3$ is rejected. Therefore, it can be said that there is no significant relationship between accounting education level and the adoption level of accounting standards in Jordan. This result is inconsistent with the prior research findings [e.g. 57, 54]. The main justification for this result is based on the results of descriptive statistic where the "Lack of holding seminars and training courses to implement standards by JICPA" is ranked fifth among the other challenges. It is necessary for JICPA to extend bridges of cooperation with universities to amend the accounting curricula in accordance with the accounting standards. Also, emphasis must be placed on holding training courses and seminars for the preparers of financial statements to improve their knowledge in the application of standards.

\section{Conclusions}

This study investigates the current status of accounting standards among Jordanian firms. In particular, it investigates the adoption level of IAS/IFRS. In addition, it examines the implementation process of IAS/IFRS in terms of difficulties and challenges. Further, the study tests empirically the effect of international institutional pressures, local legal enforcement bodies and accounting education level on accounting standards adoption level. Based on 62 responses from four sectors, it is revealed that the adoption level of IAS/IFRS among Jordanian companies is moderate. The results show no difference in the level of adoption among all sectors. In general, the study reveals that the implementation process of some standards is almost easy. Lack of government support, lack of IT systems, deficiency in the accounting legislations, costs, lack of holding seminars and training by JACPA and the complexity nature of some standards are the main challenges for the proper implementation of accounting standards.

Empirical results also show that international institutional pressure and local legal enforcement bodies have a positive and significant relationship with the adoption level of accounting standards. However, the relationship between the accounting education level and the adoption level is not significant.

Based on the results of the study, policy makers in Jordanian firms along with different legal institutions should develop a solid strategic plan to ensure that standards are fully adopted. JICPA has a double responsibility for holding all the necessary training courses and seminars related to standards implementation. In addition, JACPA should coordinate with IASB to address any issues related to standards adoption and implementation in Jordan. Further, JACPA should collaborate with the government to provide the necessary financial, technical and legal support for Jordanian firms to 
fully adopt and apply accounting standards.

The current study limitations can be controlled by expanding the study sample in the future studies and by employing additional factors to empirically show their effect on the adoption and implementation levels of accounting standards in Jordan and other countries. In addition, future comparative studies in this topic are necessary to address the different issues of accounting standards. Further, the impact of accounting standards adoption on different accounting reporting issues will be another important research opportunity. However, future studies may increase the number of standards and classify them according to their adoption level using the three-point-scale level: high, moderate and low. Similar procedure also can be used for difficulty level. Similarly, future study should differentiate empirically between the adoption level and the implementation level of accounting standards. Most important, future study may be employed across several sectors to show if there are any differences among different sectors in the level of adoption or implementation in particular standard or standards.

\section{REFERENCES}

[1] Bendovschi, O. "Dimensions of Difference between Domestic Accounting Standards and IFRS and Potential Determinants-the Case of Emerging Countries, with Focus on Romania", Audit Financiar, XIII,vol. 13, no. 125, pp.101-109, 2015.

[2] Ball, R, "International Financial Reporting Standards (IFRS): pros and cons for investors", Accounting and Business Research, vol. 36:sup1, pp. 5-27, 2006. DOI: 10.1080/00014788.2006.9730040

[3] Srivastava, A., \& Bhutani, P, "IFRS in India: Challenges and Opportunities," IUP Journal of Accounting Research \& Audit Practices, vol.11, no. 2, pp.6-32, 2012.

[4] Albu, N., \& Albu, C. N, "IFRS application in Central and South-Eastern European countries," Accounting \& Management Information Systems, vol. 13, no. 2, pp.182-197, 2014.

[5] Hoogendoorn, M, "International accounting regulation and IFRS implementation in Europe and beyond-experiences with first-time adoption in Europe," Accounting in Europe, vol. 3, no.1, pp. 23-26, 2006. https://doi.org/10.1080/09638 180600920087

[6] Jermakowicz, E. K., \& Gornik-Tomaszewski, S, "Implementing IFRS from the perspective of EU publicly traded companies," Journal of International Accounting, Auditing and Taxation, vol.15, no. 2, pp.170-196, 2006. https://doi.org/10.1016/j.intaccaudtax.2006.08.003

[7] Horton, J., Serafeim, G., \& Serafeim, I, "Does Mandatory IFRS Adoption Improve the Information Environment?," Contemporary Accounting Research, vol.30, no. 1, pp. 388-423, 2013. https://doi.org/10.1111/j.1911-3846.2012.0 1159.x
[8] Bradbury, M. E., \& Scott, T, "What accounting standards were the cause of enforcement actions following IFRS adoption?," Accounting \& Finance, pp.1-22, 2020. https://doi.org/10.1111/acfi.12661

[9] Key, K. G., \& Kim, J. Y, "IFRS and accounting quality: Additional evidence from Korea," Journal of International Accounting, Auditing and Taxation, vol. 39, 2020. https://doi.org/10.1016/j.intaccaudtax.2020.100306.

[10] Tawiah, V., \& Boolaky, P, “Consequences and determinants of IFRS convergence in India," International Journal of Accounting \& Information Management, vol. 28, no. 2, pp.303-322, 2020. https://doi.org/10.1108/IJAIM-06-20190062

[11] Bertrand, J., de Brebisson, H., \& Burietz, A, "Why choosing IFRS? Benefits of voluntary adoption by European private companies," International Review of Law and Economics, vol. 65, 2021. https://doi.org/10.1016/j.irle.2020.105968.

[12] Samaha, k., \& Khlif, H, "Compliance with IAS/IFRS and its Determinants: A Meta-Analysis," Journal of Accounting Business \& Management, vol. 23, no. 1, pp. 41-63, 2016.

[13] El-Helaly, M., Ntim, C. G., \& Al-Gazzar, M, "Diffusion theory, national corruption and IFRS adoption around the world," Journal of International Accounting, Auditing and Taxation, vol. 38, 2020.https://doi.org/10.1016/j.intaccaudt ax.2020.100305

[14] Flynn, S, "Globalization \& International Accounting," Research Starters Academic Topic Overviews: EBSCO Research Starters, 1-7, Great Neck Publishing, 2014.

[15] Jagannath, K. M., \& Nanjegowda, K, "The Impact of Mandatory Accounting Standards on the Harmonization of Accounting Practices," The IUP Journal of Accounting Research and Audit Practices, vol. 7, no.1, pp. 7-23, 2008.

[16] Erzsébet, S., \& Suhányi, L, "Application of international financial reporting standards (IFRS) in the Slovak republic," Agricultural Management, vol. 13, no.3, pp. 267-274, 2011.

[17] Aljifri, K., \& Khasharmeh, H, "An investigation into the suitability of the international accounting standards to the United Arab Emirates environment," International Business Review, vol.15, no.5, pp.505-526, 2006. https://doi.org/10. 1016/j.ibusrev.2006.05.009

[18] Alsaqqa, I., \& Sawan, N, "The Advantages and the Challenges of Adopting IFRS into UAE Stock Market," International Journal of Business \& Management, vol. 8, no. 19, pp.1-23, 2013. https://doi.org/10.5539/ijbm.v8n19p1

[19] Sprague, C, "Financial Statements," Research Starters Academic Topic Overview: EBSCO Research Starters.", 1-7. Great Neck Publishing, 2014.

[20] Gornik-Tomaszewski, S., \& Showerman, S, "IFRS in the United States: Challenges and Opportunities," Review of Business, vol. 30, no. 2, pp. 59-71, 2010.

[21] Barlev, B., \& Haddad, J. R, "Harmonization, comparability, and fair value accounting," Journal of Accounting, Auditing \& Finance, vol. 22, no. 3, pp. 493-509, 2007. https://doi.org/10.1177/0148558X0702200307

[22] Deloitte \& Touche. (2013).IAS Plus, IFRS in Your Pocket 2013, Online Available from: http://www.iasplus.com/en/p ublications/global/ifrs-in-your-pocket/ifrs-in-your-pocket-2 
013

[23] Ramcharran, H, “The Need for International Accounting Harmonization: An Examination and Comparison of the Practices of Russian Banks," American Business Review, vol. 18 , no. 1 , pp. $1-8,2000$.

[24] Reddy, G. S., \& Desai, R, "Explanatory Process for Adoption of IFRS in Indian Banks," IUP Journal of Accounting Research \& Audit Practices, vol. 14, no. 1, pp. 7-20, 2015.

[25] McGregor, W, "Personal Reflections on Ten Years of the IASB," Australian Accounting Review, vol. 22, no. 3, pp. 225-238, 2012. https://doi.org/10.1111/j.1835-2561.2012.0 0184.x

[26] Al-Akra, M., Jahangir Ali, M., \& Marashdeh, O, "Development of accounting regulation in Jordan," The International Journal of Accounting, vol. 44, no. 2, pp. 163-186, 2009. https://doi.org/10.1016/j.intacc.2009.03.00 3

[27] Al-Akra, M., Eddie, I. A., \& Ali, M. J, "The influence of the introduction of accounting disclosure regulation on mandatory disclosure compliance: Evidence from Jordan", The British Accounting Review, vol. 42, no. 3, pp. 170-186, 2010. https://doi.org/10.1016/j.bar.2010.04.001

[28] Callao, S., Jarne, J. I., \& Laínez, J. A, “Adoption of IFRS in Spain: Effect on the comparability and relevance of financial reporting," Journal of International Accounting, Auditing and Taxation, vol.16, no. 2, pp. 148-178, 2007. https://doi.org/10.1016/j.intaccaudtax.2007.06.002

[29] Liu, C., Yao, L. J., Hu, N., \& Liu, L, “ The Impact of IFRS on Accounting Quality in a Regulated Market an Empirical Study of China," Journal of Accounting, Auditing \& Finance, vol.26, no. 4, pp. 659-676, 2011. https://doi.org/10.1177/0148558X11409164

[30] Terzi, S., Oktem, R., \& Sen, I. K, "Impact of Adopting International Financial Reporting Standards: Empirical Evidence from Turkey", International Business Research, vol. 6, no. 4, pp. 55-66, 2013. https://doi.org/10.5539/ibr.v $6 \mathrm{n} 4 \mathrm{p} 55$

[31] Aksu, M., and Espahbodi, H, "The Impact of IFRS Adoption and Corporate Governance Principles on Transparency and Disclosure: The Case of Borsa Istanbul," Emerging Markets Finance \& Trade, vol. 52, no. 4, pp. 1013-1028, 2016. https://doi.org/10.1080/1540496X.2014.998570

[32] Săcărin, M., Bunea, S., \& Girbina, M. M, " Perceptions of accounting professionals on IFRS application at the individual financial statements: evidence from Romania," Accounting and Management Information Systems, vol. 12, no. 3, pp. 405-423, 2013.

[33] Grabinski K., Kedzior M., \& Krasodomska J, "The Polish accounting system and IFRS implementation process in the view of empirical research," Accounting and Management Information Systems, vol. 13, no.2, pp. 281-310, 2014.

[34] Khan, S., Anderson, M., Warsame, H., \& Wright, M, "Do IFRS-Based Earnings Announcements Have More Information Content than Canadian GAAP-Based Earnings Announcements?," Accounting Perspectives, vol. 14, no. 3, pp. 276-302, 2015. https://doi.org/10.1111/1911-3838.120 52
[35] DiPonio., T, "Disentangling the IFRS 1 disclosure: Observations from the early adoption of IFRS in Canada," Academy of Accounting and Financial Studies Journal, vol. 20, no. 1, pp. 35-46, 2016.

[36] Gannon, D. J., \& Ashwal, A, "Financial Reporting Goes Global," Journal of Accountancy, vol. 198, no. 3, pp. 43-47, 2004.

[37] Eng, L. L., Sun, L., \& Vichitsarawong, T, “Are International Financial Reporting Standards-Based and US GAAPBased Accounting Amounts Comparable? Evidence From US ADRs," Journal of Accounting, Auditing \& Finance, vol. 29 , no. 2 , pp. 163-187, 2014. https://doi.org/10.1177/0 $148558 \times 14521212$

[38] Yamamoto, T, "Fair value of investment property and independent appraisers: the experience in the UK and Japan,” Appraisal Journal, Spring, no. 2, pp. 138-154, 2014.

[39] Mogul, S. S, "Harmonization of Accounting Standards," Chartered Accountant, January, pp. 681-684, 2003.

[40] Larson, R. \& Street, D, "Convergence with IFRS in an expanding Europe: progress and obstacles identified by large accounting firms' survey," Journal of International Accounting, Auditing and Taxation, vol. 13, no. 20, pp. 89-119,

2004.https://doi.org/10.1016/j.intaccaudtax.2004.09.002

[41] Marra, A., \& Mazzola, P, "Is Corporate Board More Effective Under IFRS or "It's Just an Illusion"?," Journal of Accounting, Auditing \& Finance, vol. 29, no.1, pp. 31-60, 2014. https://doi.org/10.1177/0148558X13512405

[42] Şenyiğit, Y. B., "Determinants of voluntary IFRS adoption in an emerging market: Evidence from Turkey", Accounting and Management Information Systems, vol. 13, no.3, pp. 449-465, 2014.

[43] Coetzee, S. A., \& Schmulian, A, "The effect of IFRS adoption on financial reporting pedagogy in South Africa," Issues in Accounting Education, vol. 28, no. 2, pp. 243-251, 2012. https://doi.org/10.2308/iace-50386

[44] Hussain, M., Islam, M. M., Gunasekaran, A., \& Maskooki, $\mathrm{K}$, "Accounting standards and practices of financial institutions in GCC countries," Managerial Auditing Journal, vol. 17, no.7, pp. 350-362, 2002.https://doi.org/10.1108/02686900210437453

[45] Desoky, A. M, “An Empirical Investigation of International Accounting Harmony-Evidence from Egypt, Jordan and GCC Countries," Journal of Accounting, vol.3, no.1, pp. 77-101, 2013.

[46] Alp, A., \& Ustundag, S, "Financial reporting transformation: The experience of Turkey" Critical perspectives on Accounting, vol. 20, no.5, pp. 680-699, 2009. https://doi.org/10.1016/j.cpa.2007.12.005

[47] Balsari, C., \& Varan, S, "IFRS implementation and studies in Turkey," Accounting \& Management Information Systems, vol.13, no. 2, pp. 373-399, 2014.

[48] Zaidi, S., \& Paz, V, "The impact of IFRS adoption: A literature review," Journal of Theoretical Accounting Research, vol.10, no. 2, pp. 116-141, 2015.

[49] Sahlian, D., Botea, M., \& TRaşcă, D. L, "Fair value hedging, between opportunity and necessity," Theoretical \& Applied 
Economics, vol. 20, no. 12, pp. 97-104, 2013.

[50] Hail, L., Leuz, C., \& Wysocki, P, "Global Accounting Convergence and the Potential Adoption of IFRS by the U.S. (Part II): Political Factors and Future Scenarios for U.S. Accounting Standards," Accounting Horizons, vol. 24, no. 4, pp. 567-588, 2010. doi:10.2308/acch.2010.24.4.567

[51] Srivastava, A., \& Gupta, P, “Adoption and Implementation of IFRS in India: A Corporate Experience," IUP Journal of Accounting Research \& Audit Practices, vol. XIII, no. 4, pp.7-24, 2014.

[52] Kılıç, M., Uyar, A., \& Ataman, B., "Preparedness for and perception of IFRS for SMEs: evidence from Turkey, "Accounting and Management Information Systems, vol. 13, no.3, pp. 492-519, 2014.

[53] Ampofo, A. A., \& Sellani, R. J, "Examining the differences between United States Generally Accepted Accounting Principles (US GAAP) and International Accounting Standards (IAS): implications for the harmonization of accounting standards," Accounting Forum, vol. 29, no. 2, pp. 219-231, 2005.https://doi.org/10.1016/j.accfor.2004.11 .002

[54] Zehri, F., \& Chouaibi, J, "Adoption determinants of the International Accounting Standards IAS/IFRS by the developing countries," Journal of Economics Finance and Administrative Science, vol. 18, no. 35, pp. 56-62, 2013. https://doi.org/10.1016/S2077-1886(13)70030-1

[55] Li, S, "Does mandatory adoption of International Financial Reporting Standards in the European Union reduce the cost of equity capital?," The Accounting Review, vol. 85, no. 2, pp. 607-636,2010.https://doi.org/10.2308/accr.2010.85.2.6 07

[56] Mir, M. Z., \& Rahaman, A. S, "The adoption of international accounting standards in Bangladesh: an exploration of rationale and process," Accounting, Auditing \& Accountability Journal, vol. 18, no. 6, pp. 816-841, 2005. https://doi.org/10.1108/09513570510627720

[57] Lasmin, R, “An institutional perspective on international financial reporting standards adoption in developing countries," Academy of Accounting and Financial Studies Journal, vol. 15, no. 2, pp. 61-71, 2011.

[58] Black, E. L, "IFRS Convergence and Adoption: Challenges and Opportunities," Journal of International Accounting Research, vol. 11, no. 1, pp. 1-3, 2012.https://doi.org/10.2308/jiar-10230

[59] Alon, A, "Complexity and Dual Institutionally: The Case of IFRS Adoption in Russia," Corporate Governance: An International Review, vol. 21, no. 1, pp. 42-57, 2013. https://doi.org/10.1111/j.1467-8683.2012.00927.x

[60] Wieczynska, M, "The "Big" Consequences of IFRS: How and When Does the Adoption of IFRS Benefit Global Accounting Firms?," The Accounting Review, vol.91, no. 4, pp. 1257-1283, 2016. https://doi.org/10.2308/accr-51340

[61] Alia, M., \& Joel,B, "Environmental obstacles associated with the adoption of IFRSs in the Arab world: Evidence from Jordan," World of Accounting Science, vol. 1, no. 13, pp. 23-84, 2011.

[62] Mande, B, "Emerging Nations and Financial Reporting
Complex: A case for IFRS adoption in Nigeria," Journal of Finance, Accounting \& Management, vol. 5, no. 2, pp. 1-23, 2014.

[63] Damak-Ayadi, S., Sassi, N., \& Bahri, M, "Cross-country determinants of IFRS for SMEs adoption," Journal of Financial Reporting and Accounting, vol. 18, no. 1, pp. 147-168,2020.https://doi.org/10.1108/JFRA-12-2018-0118

[64] Sharairi, M. H, "Factors that influenced the adoption of IFRS by Islamic banks in the UAE, "Accounting Research Journal, vol. 33, no. 1, pp. 75-91, 2020.https://doi.org/10.1108/ARJ-11-2017-0185

[65] Brown, P., Preiato, J., \& Tarca, A, "Measuring Country Differences in Enforcement of Accounting Standards: An Audit and Enforcement Proxy," Journal of Business Finance and Accounting, vol. 41, no. 1-2, pp. 1-52, 2014. https://doi.org/10.1111/jbfa.12066

[66] Hegarty, J., Gielen, F., \& Hirata Barros, A. C. (2004). Implementation of international accounting and auditing standards. Lessons learned from the World Bank's auditing and accounting ROSC program. Washington DC. Online Available from:https://openknowledge.worldbank.org/bitst ream/handle/10986/14354/419530WP0Lesso1ned1ROSC1 AA01PUBLIC1.pdf? sequence $=1 \&$ isAllowed $=y$

[67] Wu, J. S., \& Zhang, I. X, “The Adoption of Internationally Recognized Accounting Standards Implications for the Credit Markets," Journal of Accounting, Auditing \& Finance, vol. 29, no. 2, pp. 95-128, 2014.https://doi.org/10.1177/0148558X14524420

[68] Ionaşcu, M., Ionaşcu, I., Săcărin, M., \& Minu, M, "IFRS adoption in developing countries: the case of Romania," Accounting \& Management Information, vol. 13, no. 2, pp. 311-350, 2014.

[69] Pekdemir, R., \& Türel, A, “An attempt to understand compliance degree of implementing international standards in accountancy: the Turkey experience." Academy of Accounting \& Financial Studies Journal, vol. 18, no. 1, pp. 49-63, 2014.

[70] Burnett, B. M., Gordon, E. A., Jorgensen, B. N., \& Linthicum, C. L, "Earnings Quality: Evidence from Canadian Firms' Choice between IFRS and US GAAP”, Accounting Perspectives, vol. 14, no. 3, pp. 212-249, 2015. https://doi.org/10.1111/1911-3838.12051

[71] LeJeune, A, "An examination of united states certified public accountants' need for IFRS-related continuing professional education," International Journal of Business, Accounting, and Finance, vol. 9, no.1, pp. 90-113, 2015.

[72] Akgün, A. İ, "Mandatory Application Of International Financial Reporting Standards: Influence Process Aimed At Members Of The Accounting Profession," The Journal of Accounting and Finance, July, pp. 173-193, 2012.

[73] Chen, S., Sun, Z., \& Wang, Y, “ Evidence from China on whether harmonized accounting standards harmonize accounting practices, "Accounting Horizons, vol. 16, no. 3, pp.

183-197, 2002.https://doi.org/10.2308/acch.2002.16.3.183

[74] Jermakowicz, E. K, "Effects of adoption of international financial reporting standards in Belgium: the evidence from BEL-20 companies," Accounting in Europe, vol. 1, no. 1, 
pp. 51-70, 2004.https://doi.org/10.1080/096381804200027 0811

[75] Al-Shammari, B., Brown, P., \& Tarca, A, “An investigation of compliance with international accounting standards by listed companies in the Gulf Co-Operation Council member states," The International Journal of Accounting, vol. 43, no. 4, pp.425-447,2008.https://doi.org/10.1016/j.intacc.2008.0 9.003

[76] Dayyala, N., Zaidi, S. K. R., \& Bagchi, K, "Diffusion of
IFRS using innovation diffusion models, “ International Journal of Accounting \& Information Management, vol. 28, no. 4, pp. 685-701, 2020.https://doi.org/10.1108/IJAIM-01 $-2020-0002$

[77] Perry, R. H., Isabella, M., \& Charlotte, B, "SPSS explained," 2nd ed, Routledge, London and New York, 2014, pp. 1-372.

[78] Al - Htaybat, K, "IFRS adoption in emerging markets: The case of Jordan, "Australian Accounting Review, vol. 28, no. 1, pp. 28-47, 2018. https://doi.org/10.1111/auar.12186 